\title{
THE CONCEPTION RATE OF EWES AFTER ARTIFICIAL INSEMINATION AT DIFFERENT TIMES DURING OESTRUS*
}

\author{
D. AMIR AND H. SCHINDLER \\ Volcani Institute of Agricultural Research, Bet Dagan, Israel \\ (Received 20th April 1971, accepted 23rd August 1971)
}

It is generally accepted that in cattle the conception rate depends upon the time of insemination in relation to the time of ovulation, considering the unequal life-span of the gametes and the time necessary for sperm transport and capacitation (Asdell, 1955). Accordingly, practical recommendations have been put forward as to the time during oestrus when insemination will result in the optimum conception rate (Salisbury \& VanDemark, 1961).

Studies made in ewes gave variable results, with the optimum time for insemination coinciding with the first half of oestrus (Sinclair, 1957; Morrant \& Dun, 1960; Restall, 1963; Jones, Martin \& Lapwood, 1968; Mattner \& Braden, 1969), mid-oestrus (Kardymovic, Marsakova \& Pavljucek, 1934; Carbonero-Bravo, 1955) or the later stages of oestrus (Anderson, 1941; Restall, 1961; Schindler, Eyal \& Volcani, 1961; Steklenev, 1961).

In view of the potential importance of artificial insemination in sheep breeding, the present study was undertaken in order to obtain additional information on the relationship between the time of insemination and the conception rate.

A total of 209 mature dry Awassi ewes were inseminated during 3 consecutive years, between August and November, the season when the ewes were in full sexual activity (Amir \& Volcani, 1965). The onset and duration of heat was determined by teasing with aproned rams at 4-hr intervals. A single insemination was performed on each ewe, at 08.00 hours, immediately after teasing. Thirtyone ewes were inseminated either before the onset of the expected oestrus or after the end of oestrus, and 178 ewes were inseminated over a range from ' 0 to $4 \mathrm{hr}$ ' to ' 36 to $40 \mathrm{hr}$ ' after the onset of oestrus. The teasing of the ewes during the whole period of oestrus ensured an equal frequency of contacts with rams and enabled us to relate the time of inseminations to the end of oestrus.

Semen was collected with an artificial vagina from fifteen rams in a random sequence; one ejaculate was generally used for not more than five inseminations. The semen was kept at about $30^{\circ} \mathrm{C}$ until insemination, which was carried out within $30 \mathrm{~min}$ of collection. Semen $(0.1 \mathrm{ml})$ was deposited in the opening of the cervical canal. The conception rate was assessed as the rate of ewes lambing.

The conception rate was found to be rather uniform regardless of the stage of oestrus at which the ewes were inseminated (Table 1). Only inseminations

* Contribution from the Volcani Institute of Agricultural Research, Bet Dagan, Israel. 1970 Series, No. $1715 \mathrm{E}$. 
carried out 0 to $4 \mathrm{hr}$ after the onset of oestrus resulted in a lower conception rate. The conception rate of ewes inseminated either before the onset or after the end of oestrus was very low (Table 2).

The fact that a lower conception rate was obtained from inseminations carried out 0 to $4 \mathrm{hr}$ after the onset of oestrus did not appear to be related to ageing of the spermatozoa, since by relating the results to the end of oestrus (Table 1), it can be seen that even a time interval of $40 \mathrm{hr}$ from insemination to end of oestrus did not influence the conception rate. Since the end of oestrus

TABLE 1

RESULTS OF INSEMINATIONS GARRIED OUT AT DIFFERENT TIMES DURING OESTRUS

\begin{tabular}{|c|c|c|c|c|c|}
\hline \multicolumn{3}{|c|}{ Grouping in relation to onset of oestrus } & \multicolumn{3}{|c|}{ Grouping in relation to end of oestrus } \\
\hline $\begin{array}{c}\text { Hours from } \\
\text { onset of } \\
\text { oestrus }\end{array}$ & $\begin{array}{c}\text { No. of } \\
\text { inseminated } \\
\text { ewes }\end{array}$ & $\begin{array}{c}\text { No. of } \\
\text { lambings }\end{array}$ & $\begin{array}{c}\text { Hours } \\
\text { before end } \\
\text { of oestrus }\end{array}$ & $\begin{array}{c}\text { No. of } \\
\text { inseminated } \\
\text { ewes }\end{array}$ & $\begin{array}{c}\text { No. of } \\
\text { lambings }\end{array}$ \\
\hline $\begin{array}{l}0 \text { to } 4 \\
4 \text { to } 8 \\
8 \text { to } 12 \\
12 \text { to } 16 \\
16 \text { to } 20 \\
20 \text { to } 24 \\
24 \text { to } 28 \\
28 \text { to } 32 \\
32 \text { to } 36 \\
36 \text { to } 40\end{array}$ & $\begin{array}{l}20 \\
17 \\
17 \\
13 \\
21 \\
19 \\
21 \\
16 \\
18 \\
16\end{array}$ & $\begin{array}{r}9 \\
15 \\
15 \\
10 \\
17 \\
13 \\
17 \\
14 \\
12 \\
9\end{array}$ & $\begin{array}{c}0 \text { to } 4 \\
4 \text { to } 8 \\
8 \text { to } 12 \\
12 \text { to } 16 \\
16 \text { to } 20 \\
20 \text { to } 24 \\
24 \text { to } 28 \\
28 \text { to } 32 \\
32 \text { to } 36 \\
36 \text { to } 40\end{array}$ & $\begin{array}{r}23 \\
22 \\
16 \\
22 \\
14 \\
23 \\
19 \\
18 \\
6 \\
15\end{array}$ & $\begin{array}{r}14 \\
18 \\
14 \\
17 \\
8 \\
15 \\
15 \\
14 \\
5 \\
11\end{array}$ \\
\hline Total & 178 & 131 & Total & 178 & 131 \\
\hline
\end{tabular}

TABLE 2

RESULTS FROM INSEMINATIONS CARRIED OUT BEFORE THE ONSET OR AFTER THE END OF OESTRUS

\begin{tabular}{|c|c|c|c|c|c|}
\hline \multicolumn{3}{|c|}{ Grouping in relation to onset of oestrus } & \multicolumn{3}{|c|}{ Grouping in relation to end of oestrus } \\
\hline $\begin{array}{c}\text { Hours before }(-) \\
\text { or after }(+) \text { the } \\
\text { onset }(0 \mathrm{hr}) \text { of } \\
\text { oestrus }\end{array}$ & $\begin{array}{l}\text { No. of } \\
\text { insemi- } \\
\text { nated } \\
\text { ewes }\end{array}$ & $\begin{array}{c}\text { No. of } \\
\text { lambings }\end{array}$ & $\begin{array}{c}\text { Hours before }(-) \\
\text { or after }(+) \text { the } \\
\text { end }(0 \mathrm{hr}) \text { of } \\
\text { oestrus }\end{array}$ & $\begin{array}{l}\text { No. of } \\
\text { insemi- } \\
\text { nated } \\
\text { ewes }\end{array}$ & $\begin{array}{c}\text { No. of } \\
\text { lambings }\end{array}$ \\
\hline $\begin{array}{c}-24 \text { to }-12 \\
-12 \text { to } 0 \\
>+32\end{array}$ & $\begin{array}{r}9 \\
8 \\
14\end{array}$ & $\begin{array}{l}1 \\
2 \\
3\end{array}$ & $\begin{array}{r}>-48 \\
-48 \text { to }-36 \\
0 \text { to }+12\end{array}$ & $\begin{array}{r}7 \\
10 \\
14\end{array}$ & $\begin{array}{l}0 \\
3 \\
\mathbf{3}\end{array}$ \\
\hline
\end{tabular}

coincides, on the average, with ovulation (McKenzie \& Terrill, 1937; Schindler \& Amir, 1972), this time interval is indicative of the duration of the fertile life of the spermatozoa. Occasionally, their fertile life may be even longer, as shown by the results of the pro-oestrous inseminations (Table 2). It seems, therefore, that the lowered conception rate from inseminations early in oestrus is connected with conditions in the reproductive tract of the ewe rather than with senescence of the spermatozoa. The poor results obtained from inseminations before the 
onset of oestrus are probably due both to senescence of the spermatozoa and to unfavourable conditions in the female reproductive tract.

The long survival time of ram spermatozoa in the genital tract of the ewe, (Quinlan, Maré \& Roux, 1933; Dauzier \& Wintenberger, 1952; Steklenev, 1961), and the short time necessary for sperm capacitation (Mattner, 1963), explain why a high conception rate can be achieved from inseminations carried out during almost all the stages of oestrus. The fact that some conceptions were obtained from inseminations after the end of oestrus, probably in late ovulating ewes (McKenzie \& Terrill, 1937; Schindler \& Amir, 1972), is also indicative of a short capacitation time.

The data presented were obtained using a dose containing 300 to $500 \times 10^{6}$ fresh spermatozoa. The results may differ when stored semen or a reduced sperm concentration is used. Under such conditions, which may influence the fertile life-span of the spermatozoa and the size of the sperm reservoir in the genital tract of the ewe (Quinlan et al., 1933; Mattner, 1966), the time range for successful inseminations may be more limited.

In the present experiment, normal cycling ewes were used. When inseminations are preceded by hormonal treatment of the ewes, an optimum time for mating in relation to induced ovulation (Dziuk, 1970), or in relation to the beginning of an induced oestrus (Robinson, 1970), has been found.

This research was financed in part by a grant made by the United States Department of Agriculture, under P.L. 480. The authors are indebted to $\mathrm{Mr}$ Y. Dimmerman for assistance.

\section{REFERENCES}

Amrr, D. \& Volcani, R. (1965) The sexual season of the Awassi fat-tailed ewe. F. agric. Sci., Camb. $64,83$.

Anderson, J. (1941) Further investigations on artificial insemination of sheep. F. agric. Sci., Camb. 31, 354.

Asdeld, S. A. (1955) Cattle fertility and sterility, p. 101. Little, Brown \& Co., Boston.

CARBonero-Bravo, D. (1955) La inseminacion artificial en la karakulizacion de algunas razas ovinas expanolas. Rev. Patron. Biol. anim. 1, 199.

DAUZier, L. \& WinTENBerger, S. (1952) Recherches sur la fécondation chez les mammifères; Durée du pouvoir fécondant des spermatozoïdes de bélier dans le tractus génital de la brebis et durée de la période de fécondité de l'oeuf après l'ovulation. C. R. Séanc. Soc. Biol. 146, 660.

Dzruk, P. (1970) Estimation of optimum time for insemination of gilts and ewes by double-mating at certain times relative to ovulation. F. Reprod. Fert. 22, 277.

Jones, R. C., MARTtN, I. C. A. \& LAPWOOD, K. R. (1968) Studies of the artificial insemination of sheep; the effects on fertility of diluting ram semen, stage of oestrus of the ewe at insemination, and injection of synthetic oxytocin. Aust. F. agric. Res. 20, 141.

Kardymovic, M., Marsakova, A. \& Pavljucek, V. (1934) Probl. Zivotn. 5, 105. Cited by Asdell, S. A. (1964) Patterns of mammalian reproduction, p. 636. Cornell University Press, Ithaca, New York.

McKenzIE, F. F. \& TrRRILl, C. E. (1937) Estrus, ovulation, and related phenomena in the ewe. Res. Bull. Mo. agric. Exp. Stn. No. 264.

MattNer, P. E. (1963) Capacitation of ram spermatozoa and penetration of the ovine egg. Nature, Lond. 199, 772.

MAtTNER, P. E. (1966) Formation and retention of the spermatozoa reservoir in the cervix of the ruminant. Nature, Lond. 212, 1479.

Mattiner, P. E. \& Braden, A. W. H. (1969) Effect of time of insemination on the distribution of spermatozoa in the genital tract in ewes. Aust. F. biol. Sci. 22, 1283.

Morrant, A. J. \& Dun, R. S. (1960) Artificial insemination of sheep. II. Techniques and equipment used at Trangie Agricultural Experiment Station. Aust. vet. F. 36, 1. 
QuinLan, J., Maré, G. S. \& Roux, L. L. (1933) A study of the duration of motility of spermatozoa in the different regions of the reproductive tract of the Merino ewe. Onderstepoort F. vet. Sci. Anim. Ind. 1, 135.

Restall, B. G. (1961) Artificial insemination of sheep. VI. The effect of post-inseminal coitus on percentage of ewes lambing to a single insemination. Aust. vet. 7. 37, 70.

Restall, B. G. (1963) The relationship between oestrus, vaginal mucus and ovulation, p. 67. Proc. Conf. Artif. Breed. of Sheep in Australia, 1961. Ed. E. M. Roberts. Univ. N.S.W.

Robinson, T. J. (1970) Fertility following synchronization of oestrus in the sheep with intravaginal sponges. II. Effect of dose of progestagen and rate of absorption. Aust. F. agric. Res. 21, 783.

Salisbury, G. W. \& VanDemark, N. L. (1961) Physiology of reproduction and artificial insemination of cattle, p. 454. Freeman, San Francisco.

Schindler, H. \& Amir, D. (1972) The length of oestrus, duration of phenomena related to oestrus and ovulation time in the local fat-tailed Awassi ewe. F. agric. Sci., Camb. 28 (in press)

Schindler, H., Eyal, E. \& Volcani, R. (1961) The conception rate of ewes in relation to the viscosity of the cervical secretion and the condition of the os uteri at the time of insemination. Refuah vet. $18,160$.

SincLAir, A. N. (1957) Effect of variation of time of mating, mating frequency and semen dose rate on conception in Merino sheep. Aust. vet. F. 33, 88.

Steklenev, E. P. (1961) Potential and actual fertility of Ascanian Finewool ewes. In: Razvitie ovcevodstva na juge Ukrainy. Sbornik statei, p. 60. Kiev: Ukrainian Academy of Agricultural Sciences. (Anim. Breed. Abstr. 30, 2631). 